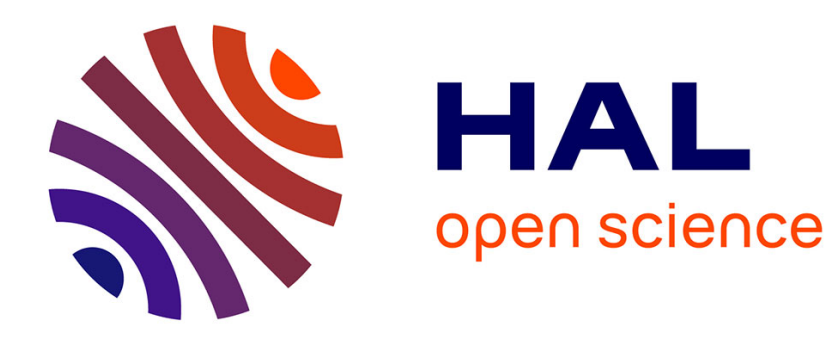

\title{
The Governance Paradox in Megaprojects
}

\author{
Lise Arena, Eamonn Molloy
}

\section{To cite this version:}

Lise Arena, Eamonn Molloy. The Governance Paradox in Megaprojects. Entretiens Jacques Cartier, 2010, Lyon, France. pp.NC. halshs-00721622

\section{HAL Id: halshs-00721622 \\ https://shs.hal.science/halshs-00721622}

Submitted on 28 Jul 2012

HAL is a multi-disciplinary open access archive for the deposit and dissemination of scientific research documents, whether they are published or not. The documents may come from teaching and research institutions in France or abroad, or from public or private research centers.
L'archive ouverte pluridisciplinaire HAL, est destinée au dépôt et à la diffusion de documents scientifiques de niveau recherche, publiés ou non, émanant des établissements d'enseignement et de recherche français ou étrangers, des laboratoires publics ou privés. 


\title{
"The Governance Paradox in Megaprojects"
}

\section{Contribution to the book project \\ Communication et grands projets: Les nouveaux défis (provisional title)}

\author{
Lise Arena ${ }^{\dagger, \ddagger}$ and Eamonn Molloy \\ ${ }^{\dagger}$ University of Nice Sophia-Antipolis, GREDEG, CNRS, France \\ ${ }^{\ddagger}$ BT Centre for Major Programme Management, Saïd Business School, University of Oxford, UK
}

Corresponding author: lise.arena@gredeg.cnrs.fr 


\section{INTRODUCTION}

This chapter explores a theoretical and practical paradox in megaprojects. According to transaction cost economics (Williamson, 1975) high uncertainty, high asset specificity, situated knowledge and the high frequency of transactions associated with megaprojects should drive managers to internalise resources and to rely on relational communication and informal contracts. However, in the context of mega-projects this presents the following paradox: managerial incentives to invest in internal resources through vertical integration are limited because of fixed time horizons and obdurate delivery deadlines; yet, the alternative of outsourcing and contract management through the market mechanism based on formal communication implies the escalation of transaction costs. This research therefore seeks to identify how practitioners might resolve this issue through enhanced communication as well as more efficient collaboration practices in order to overcome the technical, psychological and political barriers that impact on effective delivery of megaprojects (Flyvbjerg, 2006). This chapter also analyses the extent to which the transaction costs approach can be used to explain the economic organisation of temporary governance structures such as megaprojects.

Thus, the aim of the chapter is to provide a new conceptual framework for the understanding of megaprojects, as governance structures that rely to a large extent on communication practices for effective coordination. Following a brief overview of the difference forms of governance associated with different kinds of organisations (section I), this chapter shows that the hybrid form is, to a certain degree, the most suited to megaprojects (section II). Yet, the temporary nature of megaprojects as organisations introduces a distinctive and additional dimension to this hybrid form of governance, that is not typically considered by the transaction cost approach to organizations (section III). The notions of 'swift trust' (Meyerson et al., 1996) and of mutual knowledge in a context of communities of practice are proposed as concepts to address this lacuna. 


\section{TRANSACTION COST APPROACH AND THE GOVERNANCE PARADOX IN MEGAPROJECTS}

Organisational theories of comparative corporate governance are not new and were, to a large extent, initiated with the publication of Ronald Coase's classic article on the 'Nature of the Firm' published in Economica in 1937. Coase raised fundamental questions about the concept of the firm in economic theory and, more importantly, suggested that the comparative costs of organising transactions through markets rather than within firms were the main determinants of the scope and size of firms. In 1975, Oliver Williamson significantly elaborated Coase's theory of the firm into a transaction cost framework which gave rise to a series of publications and to the modern transaction costs approach. In particular, Williamson deepened the discussions of why firms might perform better than markets and argued that markets are coordinated by the price mechanism and rely on formal contracts (enforceable by a court and incomplete), whereas firms are coordinated by hierarchy and rely on "relational contracts" (informal agreements not adjudicated by courts which overcome the difficulties of incomplete contracts).

Over the last two decades, a series of criticisms have been addressed to Williamson's development on several grounds. While some argued that transaction costs economics (TCE) will remain "bad for practice" (Ghoshal, Moran, 1996), others questioned Williamson's dichotomous view of markets and hierarchies (Powell, 1990). As a result of the latter critique, Williamson reconsidered his polarised view of governance structures and introduced the notion of a hybrid form of organization as an intermediate structure sharing characteristics of both firms and markets. In Williamson's own words, the hybrid mode is characterized by:

“(...) semi-strong incentives, an intermediate degree of administrative apparatus, displays semi-strong adaptations of both kinds, and works out of a semi-legalistic contract law regime. As compared with market and hierarchy, which are polar opposites, the hybrid mode is located between the two of these in all five attribute respects." (Williamson, 1991: 281) 
Yet, Williamson was also careful to note that "the abstract attributes that characterize alternative modes of governance have remained obscure" (Ibid.: 269).

In this paper, we explore the question of where megaprojects, as a distinctive organisational phenomena can be positioned along this scale of governance structures. By doing so, we aim to establish a theoretical basis for explaining the extremely poor performance track record of megaprojects that has been thoroughly documented by authors such as Flyvbjerg (Flyvbjerg et al., 2002, 2004, 2005, Flyvbjerg, 2005a, 2005b, 2009). This literature has emphasised the extensive failure of megaprojects and offered three main reasons for this: technical uncertainty, psychological effects such as optimism bias and political factors such as strategic misrepresentation (Flyvbjerg, 2006). However, the focus of this literature has mainly been on the dynamics of the early planning stages of mega-projects rather than the organizational arrangements and dynamics of megaprojects at different stages of the life-cycle. We argue that the scale and scope of megaprojects in terms of budget, life-span, number of employees and social impact render them comparable to large 'permanent' organizational forms such as firms. In light of this, it is an appropriate endeavour to evaluate the extent to which organizational theory grounded in notions of relatively clear-cut governance structures such as the firm and the market can also account for the challenges associated with managing megaprojects. This observation echoes the wider point, now well established in the project management literature, that organisational theories have been underexplored in terms of their potential contribution to understanding project and temporary organisations (van Donk and Molloy, 2008). The pluridisciplinary nature of our research bringing together organizational economics and project management literature suggests that the poor performance of megaprojects cannot be understood outside an organizational conceptual framework, therefore adapting existing organizational approaches to the field of megaprojects management is justified. In this paper, we specifically focus on how communication practices might allow managers to overcome the 'make or buy' tension that is central to the governance paradox in finite megaprojects. 
Yet, we recognise that the familiar market-hierarchy dichotomy does not do justice to the notion of megaprojects and to their unique form of economic exchange. The transaction cost approach to organizations suggests sharp boundaries to firms with competitors as outside boundaries and inside managers exercising authority and opportunistic behaviour. In contrast, megaprojects typically engage in collaborations that resemble neither the "familiar alternative of arms' length market contracting" nor "the former ideal of vertical integration" (Powell, 1990: 297). On the one hand, megaprojects cannot be understood as an autonomous market form of organization, due to the nature of the contracts between the different parties of the project. Further, megaprojects are not supported by classical contract law theory since although the parties to the transaction are autonomous, they are largely dependent on each other. Moreover, the existence of dependences and strong cooperation between the different parties contradicts Williamson's definition of a market form of organization exclusively coordinated by a price mechanism and supported by bilateral relationships. Rather, megaprojects generally take place within complex and multiparty contractual relationships and the participants' behaviours are, to a large extent, sheltered from market forces. On the other hand, neither can megaprojects be understood as vertically integrated on the basis of formal fiat, as firms are. A hierarchical structure based on clear departmental boundaries, clean lines of authority, detailed reporting mechanisms and formal decision-making procedures does not reflect megaprojects' reality of sharp fluctuations, complexity and unanticipated changes that arise as a result of factors such as the political nature of the operating environment and technological novelty.

Still, according to Williamson, the choice to internalise resources (through a mechanism of vertically integrated organisation - to 'make') depends on four main variables, namely high uncertainty, high asset specificity, situated knowledge and the high frequency of transactions, all of which are pertinent in the context of megaprojects. Yet, as outlined in the introduction of this chapter, megaprojects managers do not have the option to internalise resources to the same extent as managers in 'permanent' organisations because of the temporary and finite nature of the project organization. This observation suggests a requirement for a definition of megaproject governance structures that is 
distinct from both market and hierarchy. In light of this, the obvious next step is to assess the extent to which the 'hybrid forms' of organization systematised and modelled in Williamson's seminal paper published in $1991^{1}$ apply to megaprojects.

\section{MEGAPROJECTS AS HYBRID FORMS OF ORGANIZATION?}

The notion of hybrid form refers to a diverse range of economic organizations (drawn on the market-hierarchy continuum) and led to a large amount of academic interest in the 1990s. To some scholars, the increasing trend of interest in this notion has contributed to "a rather messy situation marked by a cacophony of heterogeneous concepts, theories, and research results" (Oliver, Ebers, 1998: 550). Nevertheless, while the purpose of this section is neither to review the impressive literature already available nor to generate one more study of hybrid forms per se, as mentioned earlier, its aim is to assess the significance of megaprojects as a hybrid form of governance. The generic meaning of a hybrid form is unclear and as noted by a recent commentator, "when it comes to intermediate arrangements, the terrain is a shifting one. The vocabulary itself is not stabilized" (Menard, 2004: 347). As suggested by Powell in 1990, the continuum of governance structures is organized as follows:

"Moving from the market pole, where prices capture all the relevant information necessary for exchange, we find putting-out systems, various kinds of repeated trading, quasi-firms and subcontracting arrangements; toward the hierarchy pole, franchising, joint ventures, decentralized profit centres and matrix management are located." (Powell, 1990: 297)

Assuming that megaprojects governance structures belong to this continuum does not appear very helpful at an operational level. The governance paradox formulated in the previous section raises the question as to which hybrid form offers a solution to this paradox. The transaction cost approach implicitly assumes that organisations are orientated towards stability, growth and long-term sustainability which is in direct

\footnotetext{
${ }^{1}$ Interestingly, this notion of hybrid form was introduced by Williamson earlier in his 1985 Economic Institutions of Capitalism, in which he summarized his views as follows: "Whereas I was earlier of the view that transactions of the middle kind were very difficult to organize and hence were unstable, (...) I am now persuaded that transactions in the middle range are much more common." (Williamson, 1985: 83) However, it was only in 1991 that he formalised the concept of hybrids.
} 
contrast to the central principle of organisation of megaprojects which are orientated to delivery of specific outcomes within a finite horizon. Further, megaprojects have a range of other features that are not shared by permanent organisations, summarised by Flyvbjerg (2009).

Risk, complexity, non-standard technologies, multi-player processes and lock-in phenomena indicate a non-linear growth process which is limited by deadlines and time commitments. These temporary forms of organizations are, to a large extent, driven by an external growth in which pre-existing networks of relationships, based on trust, reputation and cooperation enable megaprojects to emerge and develop. In a way, this non-linear growth is implicitly mentioned in Williamson's analysis of joint-ventures. Interestingly, Williamson argued:

"Joint-ventures that are designed to give a respite should be distinguished from the types of hybrid modes analyzed here, which are of an equilibrium kind" (Williamson, 1991: 293).

Unfortunately, Williamson did not further develop any explanation of these 'nonequilibrium kind' of joint-ventures. Therefore, it seems that megaprojects belong to a family of organizational form in need of an explanatory theory which needs fresh insights. As a modest step in this direction, the following table represents an overview of the key differences between market, hierarchy and two hybrid forms, namely network and megaproject. The first three columns are based on Powell's well-known article published in 1990. The relevant aspect of this comparison is concerned with the key feature of megaprojects. The temporary nature of project-based organizations reveals time-limited cooperation supported by multiparty contractual relationships.

\begin{tabular}{|c|c|c|c|c|}
\hline Key Features & Market & Hierarchy & Network & Megaproject \\
\hline Normative Basis & $\begin{array}{c}\text { Contract }- \\
\text { Property Rights }\end{array}$ & $\begin{array}{c}\text { Employment } \\
\text { Relationship }\end{array}$ & $\begin{array}{c}\text { Temporary } \\
\text { Cooperation/ } \\
\text { Multiparty } \\
\text { Strengths } \\
\text { Contractual } \\
\text { Relationships }\end{array}$ \\
\hline $\begin{array}{c}\text { Means of } \\
\text { Communication }\end{array}$ & Prices & Routines & Relational & $\begin{array}{c}\text { Temporary } \\
\text { Relational - } \\
\text { Transfer of } \\
\text { knowledge }\end{array}$ \\
\hline Methods of & Haggling - Resort & Administrative Fiat & Norms of & Swift trust - \\
\hline
\end{tabular}




\begin{tabular}{|c|c|c|c|c|}
\hline Conflict Resolution & $\begin{array}{c}\text { to Courts for } \\
\text { Enforcement }\end{array}$ & - Supervision & $\begin{array}{c}\text { Reciprocity }- \\
\text { Reputational } \\
\text { Concerns }\end{array}$ & We-Rationality \\
\hline $\begin{array}{c}\text { Degree of } \\
\text { Flexibility }\end{array}$ & High & Low & Medium & Very High \\
\hline $\begin{array}{c}\text { Amount of } \\
\text { Commitment } \\
\text { Among the Parties }\end{array}$ & Low & Medium to High & $\begin{array}{c}\text { Medium to } \\
\text { High }\end{array}$ & Very High \\
\hline $\begin{array}{c}\text { Tone or Climate } \\
\text { Precision and/or } \\
\text { Suspicion }\end{array}$ & $\begin{array}{c}\text { Formal, } \\
\text { Bureaucratic }\end{array}$ & $\begin{array}{c}\text { Open Ended, } \\
\text { Mutual } \\
\text { Benefits }\end{array}$ & $\begin{array}{c}\text { Innovation, } \\
\text { Communities of } \\
\text { Practice }\end{array}$ \\
\hline $\begin{array}{c}\text { Actor Preferences } \\
\text { or Choices }\end{array}$ & Independent & Dependent & Interdependent & $\begin{array}{c}\text { Mutually } \\
\text { Interdependent }\end{array}$ \\
\hline
\end{tabular}

Table 1 - Stylised Comparisons of Four Forms of Economic Organization: Market, Hierarchy, Network and Megaproject (based on Powell, 1990: 300)

Here, the notion of temporary relates to organisations whose members may have never worked together before and who may not expect to work together again as a group (Jarvenpaa, Leidner, 1999: 792). Facilitating factors usually identified to favour trust, such as shared social norms, repeated interactions, shared experiences and anticipation of future association (Powell, 1990) are often less significant in the context of megaprojects, mainly because of their stand-alone, one-off nature. As a result, megaprojects establish their communication practices on temporary transfers of knowledge based on 'swift trust' (Meyerson, Weick, Kramer, 1996; Gold, 2005(b)) due to the need for flexibility ${ }^{2}$. Swift trust applies to social groups that include members with diverse skills, a very limited history of working together, and uncertain prospects of future collaboration. It is suited to the context of megaprojects since the theory of swift trust assumes clear role divisions among members who have well-defined specialities. The fixed-time horizons of megaprojects create few incentives for deep relationship building and prevent project members from gathering first-hand information. In particular, swift trust refers to the "willingness to trust strangers and a positive expectation that the group activity will be beneficial before it even starts" (Ibid.: 16). It is only after the project members have begun to interact that trust is maintained by a "highly active, proactive, enthusiastic, generative style of action" (Meyerson, Weick, Kramer, 1996: 180).

\footnotetext{
${ }^{2}$ More generally, it is argued that a person trusts a group when that person believes that the group "(a) makes a good-faith effort to behave in accordance with any commitments both explicit or implicit, (b) is honest in whatever negotiations preceded such commitments, and (c) does not take excessive advantage of another even when the opportunity is available" (Cummings, Bromiley, 1996: 303).
} 
Whereas the network form of governance reveals a medium degree of flexibility and a medium to high amount of commitment among the parties, the complexity inherent to and the uncertainty associated with megaprojects make both of these variables very high. In addition, innovative processes and the emergence of communities of practice could be a solution to address the high degree of flexibility required by the nature of megaprojects. In terms of actors' preferences, interdependences are the only way to execute very large projects. The need for cooperation and collaboration is a critical requirement and is achieved through the development of complementary skills, acceptance of ideas, knowledge transfer, reflection, dialogue and experimentation.

In the context of megaprojects, the solution to the governance paradox may not be the adoption of a hybrid organizational form (Williamson, 1991; Menard, 1997) combining elements of authority and market mechanisms, but instead might be an exploration of alternative forms of governance, such as communities of practice that focus on knowledge and explicitly enable the management of knowledge to be placed in the hands of practitioners (McDermott, Snyder, Wenger, 2002). The self-managing nature of these communities combines a bottom-up as well as a top-down process which encourages collective learning from past mistakes, capturing learning into remembered repositories and refined practices for future use.

In contrast with other governance forms, megaprojects are characterised by temporary cooperation between multiparty contractual actors. Communication between different members involved in a megaproject is therefore based on transfer of knowledge between various experts. Yet, as megaprojects are often one-off events (Priemus, Flyvbjerg, van Wee, 2008: 12), it is therefore often difficult to refer to past mutual knowledge to resolve problems. In this sense, mutual knowledge established in such an organisation is rather based on interactional dynamics than on direct knowledge (Cramton, 2001: 347). Mutual knowledge increases the likelihood that communication will be understood and can be established through interaction in the case of megaprojects. As a result, relationships are 
based on swift trust (Meyerson, Weick, Kramer, 1996: 167) in a context of we-rationality (Arena, Conein, 2008). According to Meyerson and his colleagues:

"Swift trust is a form of trust that is created in temporary system, a system that demonstrates behaviour that presupposes trust. Hence sources of trust like familiarity, shared experience, reciprocal disclosure, threats and deterrents, fulfilled promises, and demonstrations of non-exploitation of vulnerability - are not obvious in such system." (Meyerson, Weick, Kramer, 1996: 167)

Megaprojects' key features, such as communication, cooperation, collaboration, very high flexibility and transfers of knowledge between different parties can take three main forms: teams, communities of practice (intra- and/or inter-organizational) and epistemic communities. The exploration of alternative forms of governance is based on the literature developing the concept of communities of practice (Amin, Cohendet, 2004; Wenger, 1998) that differ significantly from work teams (Gold, 2005). While teams are formed by management and respond to specific deliverables, communities of practice emerge from a voluntary basis and have no specific deliverables imposed by the management. More specifically, Michael Bacharach provided a clear definition of what a team was; he claimed that ${ }^{3}$ :

"A team is a group of agents with a common goal which can only be achieved by appropriate combinations of individual activities. This teamwork is a species of cooperation. (...) Teams may be long-lived institutions like terrorist cells, or ephemeral products of circumstances like three passers-by giving a motorist a pushstart. Communication may be minimal (...).” (2005: xxi)

Individual members of a team tend to have private interests as well as collective incentives. However, while Bacharach and his colleagues (2005) provide a frame of analysis for the concept of "we-reasoning" or "team-reason", they do not explain as such logic of collective action may arise. Yet, they claimed that we-reasoning enables agents to reach 'coordination points' described as "many different ways in which groups of

\footnotetext{
${ }^{3}$ Michael Bacharach was a Professor of Economics and the Director of the research unit on Bounded Rationality in Economic Behaviour at Oxford University. He assumed an existing psychological tendency for individuals to see themselves as members of "teams", rather than as isolated, independent, agents. To him, there are times when their psychology leads individuals to act in accordance with the answer not to "What should I do?" but to "What should we do?". His death in 2002 left Bacharach's research programme unfinished.
} 
agents with a common goal can achieve it" (Ibid.: xxii) ${ }^{4}$. Margaret Gilbert (2005) went one step further in the analysis of teams and suggested that this specific form of cooperation was characterised by a stronger condition, related to joint-commitment that involved collective intention as well as joint responsibility (also defined as obligations to other members of the team $)^{5}$.

To a large extent though, this form of cooperation and of communication follows the rational choice paradigm and, as stated, does not provide much material about the nature of the cooperation and the communication between the different parties of a megaproject team. Hence, the solution to the governance paradox has to be found in overlapping communities - as parts of the megaproject organisation - which have a dominant mode of learning and collective behaviour to encourage the creation of knowledge repositories and refined practices in a context of high uncertainty. Whereas megaprojects managers do not have enough time to invest internally and when it is too costly for them to exclusively use resources from the market, the alternative governance structure should gather a collective of communities. This collective should have a reasonable degree of autonomy and independence, yet evolving within a structured temporary organisation ${ }^{6}$. This specific form of governance would be rather well-positioned to be highly innovative and to deal with organisational discontinuities inherent in megaprojects.

\footnotetext{
${ }^{4}$ In these specific circumstances, communication is crucial between the different parties of a megaproject. According to Bacharach, "[w]hen communication is not possible, it is far from obvious how agents will manage to identify the same coordination point as each other; and if they go for different ones there will be a 'coordination failure'. (...) This leads them to 'team reason'. In philosophy, team reasoning provides a new account of 'collective intentions' and, in its 'circumspect' variety which allows for possible 'lapsing' by some team members (...)." (Ibid.: xxii)

${ }^{5}$ In particular, Gilbert argued (2005: 25): “(...) joint commitments come about in two ways. In the primary case, each party must express to the others his or her readiness to be jointly committed with them in the relevant way, in conditions of 'common knowledge'. Roughly, these expressions must be 'entirely out in the open' from the point of view of the parties. When and only when all the expressions are made, the jointcommitment exists. In the secondary or authority-involving case, the parties jointly commit to allowing some person or body to create new joint commitments for them in some relevant domain, possibly without their knowledge. For example, the parties may jointly commit to accepting as a body that a certain person or body may make decisions for them, in effect jointly committing them to intend as a body to perform certain actions".

${ }^{6}$ The best example of this kind of organisational arrangement is, to a large extent, science-based megaprojects which gather private companies and university researchers (Knorr-Cetina, 1999).
} 
Communities of practice and epistemic communities are perhaps the most relevant types of alternative governance structures to the governance paradox of megaprojects, since they are often considered as cooperation forms in which knowledge creations are more likely to occur. Communities of practice can be seen as a way to enhance individual and collective competencies through the sharing of a common repertoire of resources. This organisational form follows the principle of self-organization and aims to improve problem-solving (working together on a specific problem when stuck) and enhances mapping knowledge and identifying gaps (knowing what is missed and what other groups could be connected to). A community of practice is therefore more than just a community of interests; it develops a genuine shared practice built on ways of addressing recurring problems, personal experiences, stories and tools. It is from this shared practice that a community's member relies on the knowledge capitalised by the community to carry out further activity. Epistemic communities take a slightly different form, as notions of autonomy and identity are weaker than in communities of practice. An epistemic community can be defined as a group of "agents working on a commonly acknowledged subset of knowledge issues and who at the very least accept a commonly understood procedural authority as essential to the success of their knowledge activities" (Cowan et al., 1998, quoted in Cohendet, Creplet, Dupouët, 2001: 7). Hence, epistemic communities are structured around a defined goal to attain and a procedural authority endowed by themselves to reach that goal. Both communities locate mutual knowledge at the heart of their functioning. In both cases, mutual knowledge consists not only of the information itself but also of the awareness that the others know it.

Both categories of communities (epistemic communities and communities of practice) are based on "management by content", supported by "distributed cognition and joined with communitarian mechanisms" (Knorr-Cetina, 1999). In particular, the form of leadership significantly differs from the vertically integrated structure of governance suggested by Williamson in the sense that leaders are not necessarily the "top" of a megaproject, nor its "spearhead" pointing forward, but are centrally placed within it. As argued by KnorrCetina in her example of physicists' experiments, managers "were centrally located in the conversation conducted within the collaboration" (Knorr-Cetina, 1999: 181). 
To summarize the different hybrid forms we have considered so far, Table 2 is reproduced from Cohendet, Creplet, Dupouët, 2001. The functional group corresponds to Williamson's concept of hierarchy.

\begin{tabular}{|c|c|c|c|c|c|c|}
\hline & Objective & Agents & $\begin{array}{l}\text { Cognitive } \\
\text { Activity }\end{array}$ & $\begin{array}{l}\text { Recruitment } \\
\text { Rule }\end{array}$ & $\begin{array}{l}\text { Knowledge } \\
\text { Production } \\
\text { and } \\
\text { Dominant } \\
\text { Learning } \\
\text { Mode } \\
\end{array}$ & $\begin{array}{c}\text { What Holds } \\
\text { the } \\
\text { Community } \\
\text { Together }\end{array}$ \\
\hline $\begin{array}{l}\text { Functional } \\
\text { Group }\end{array}$ & $\begin{array}{l}\text { Ensure a } \\
\text { given } \\
\text { function }\end{array}$ & Homogeneous & $\begin{array}{l}\text { Disciplinary } \\
\text { Specialisation }\end{array}$ & Hierarchical & $\begin{array}{l}\text { Unintended } \\
\text { Learning by } \\
\text { doing }\end{array}$ & $\begin{array}{c}\text { Education } \\
\text { Task definition }\end{array}$ \\
\hline Team & $\begin{array}{l}\text { Realise a } \\
\text { given task }\end{array}$ & Heterogeneous & $\begin{array}{l}\text { Integration of } \\
\text { functional } \\
\text { knowledge }\end{array}$ & Team's leader & $\begin{array}{l}\text { Unintended } \\
\text { Learning by } \\
\text { interacting }\end{array}$ & $\begin{array}{c}\text { Job } \\
\text { requirements } \\
\text { Common goals }\end{array}$ \\
\hline Network & $\begin{array}{c}\text { Mutually } \\
\text { negotiated } \\
\text { specialisation }\end{array}$ & Heterogeneous & $\begin{array}{l}\text { Knowledge } \\
\text { exchange }\end{array}$ & Mutual Trust & $\begin{array}{l}\text { Intended or } \\
\text { unintended } \\
\text { depending on } \\
\text { the network } \\
\text { Learning by } \\
\text { exchanging }\end{array}$ & $\begin{array}{l}\text { Need to access } \\
\text { complementary } \\
\text { knowledge }\end{array}$ \\
\hline $\begin{array}{l}\text { Community } \\
\text { of Practice }\end{array}$ & $\begin{array}{l}\text { Increase the } \\
\text { skills in a } \\
\text { given } \\
\text { practice }\end{array}$ & Homogeneous & $\begin{array}{c}\text { Accumulate } \\
\text { knowledge } \\
\text { about a given } \\
\text { practice } \\
\text { Circulation of } \\
\text { best practices }\end{array}$ & $\begin{array}{l}\text { Members } \\
\text { who select } \\
\text { themselves }\end{array}$ & $\begin{array}{l}\text { Unintended } \\
\text { Learning in } \\
\text { working }\end{array}$ & $\begin{array}{l}\text { Common } \\
\text { passion for the } \\
\text { practice }\end{array}$ \\
\hline $\begin{array}{c}\text { Epistemic } \\
\text { Community }\end{array}$ & $\begin{array}{c}\text { Produce } \\
\text { knowledge }\end{array}$ & Heterogeneous & $\begin{array}{l}\text { Construction } \\
\text { of knowledge } \\
\text { or language or } \\
\text { messages } \\
\text { Circulation of } \\
\text { codified } \\
\text { knowledge }\end{array}$ & By peers & $\begin{array}{l}\text { Intended } \\
\text { Searching }\end{array}$ & $\begin{array}{l}\text { Respect of a } \\
\text { procedural } \\
\text { authority }\end{array}$ \\
\hline
\end{tabular}

Table 2 - Five Hybrid Forms: From the Functional Group to the Epistemic Community (Cohendet, Creplet, Dupouët, 2001)

Whereas a community of practice seems to constitute the best solution to the governance paradox of megaprojects, the concept of inter-organizational communities of practice appears to be even more suited (Moingeon et al., 2005). As with other hybrid forms, inter-organizational communities of practice (IOCoP) move away from polar organizational forms such as the market and the firm, leading to the reduction of transaction costs, a better coordination of practices and collective learning from 
experience. According to recent literature, these forms of organization could be characterized by two main permanent features. The first is the "coordination of experience, knowledge and resources" and the second is the "recourse to relational, implicit devices and creation of reciprocity which define the bonds between IOCoP partners" (Ibid.). Both of these features indicate a quick and easy adaptation to complexity and unexpected situations (common to megaproject-based organizations), by integrating new parties or by modifying the modes of collaboration along the process of organizational growth.

A community of practice as an organizational solution to the governance paradox in megaprojects is reinforced by the predominant role played by fixed-time horizons and the finite nature of megaprojects. This implications of this feature is, we believe, almost completely absent from the transaction costs approach to organisations that assumes organisations are orientated towards stability, growth and sustainability. In the following therefore, we show how communities of practice can address this challenge also.

\section{NON-PERMANENCY AS A NEW DISTINCTIVE FEATURE OF MEGAPROJECTS}

As stated earlier, Williamson argued that the main determinants of the choice toward the most appropriate governance structure were related to high uncertainty, high asset specificity, and the high frequency of transactions. Interestingly, the potential implications of organizational permanency or 'temporariness' is not accounted for in his analysis. The identification of megaprojects as a hybrid form of governance structure provides an interesting case for this additional variable. The transaction cost approach generally claims that the more specific an organisation's assets are, the more the organization should internalize its related activities to reduce its transaction costs (assuming a moderate level of uncertainty). According to his conceptualisation of assetspecificity, Williamson only referred to time-related issues in his notion of "temporal 
specificity"7. Yet, the concept is used in a significantly different way than the idea of a fixed-time horizon developed here. Williamson's concept is defined as follows:

"temporal specificity is akin to technological nonseparability and can be thought of as a type of site specificity in which timely responsiveness by on-site human assets is vital". (Williamson, 1991: 290-1)

However, it could be argued that time is not correlated to asset specificity but is an independent variable which rather directly affects managers' choices between 'make' or 'buy'. Hence, the temporary nature of megaprojects, as organisations, challenges Williamson's results - even considering his analysis of hybrid forms.

In particular, the following Table focuses on the degree of asset specificity in transactions and distinguishes three different levels: strong $(++)$, semi-strong $(+)$ and weak $(0)$. In the traditional case assumed by Williamson (i.e. permanent organizations), the degree of asset specificity determines the degree of internalisation. However, in the paradox considered here, high asset specificity does impact the choice of governance differently than in the case of permanent organizations.

\begin{tabular}{|c|c|c|c|c|}
\hline & & Market & Hybrid & Hierarchy \\
\hline $\begin{array}{c}\text { Permanent } \\
\text { Organizations }\end{array}$ & $\begin{array}{c}\text { High Asset } \\
\text { Specificity }\end{array}$ & 0 & ++ \\
\hline $\begin{array}{c}\text { Low Asset } \\
\text { Specificity } \\
\text { Temporary }\end{array}$ & $\begin{array}{l}\text { High Asset } \\
\text { Specificity }\end{array}$ & ++ & + & 0 \\
\hline & Low Asset & ++ & + & 0 \\
\hline
\end{tabular}

Table 3 - Distinguishing Attributes of Market, Hybrid and Hierarchy Governance Structures in Permanent and Temporary Organizations (based on Williamson, 1991: 281)

\footnotetext{
${ }^{7}$ Williamson distinguishes 6 kinds of asset specificities: (1) site specificity, (2) physical asset specificity, (3) human-asset specificity, (4) brand name capital, (5) dedicated assets and (6) temporal specificity. For further details about this categorisation, see Williamson, 1991: 281.
} 
The time dimension is here considered as a crucial characteristic of the governance structure chosen by megaproject managers. Graphically, this idea is expressed by a nonlinear function (S curve) which tends toward internalisation in a permanent context in the long-run (with the highest degree of internalisation corresponding to high asset specificity). By contrast though, in the case of temporary organisations (such as megaprojects), the blue circle drawn on the following graph represents the difficulty for managers to internalise in the case of fixed-time horizons.

Degree of Internalisation

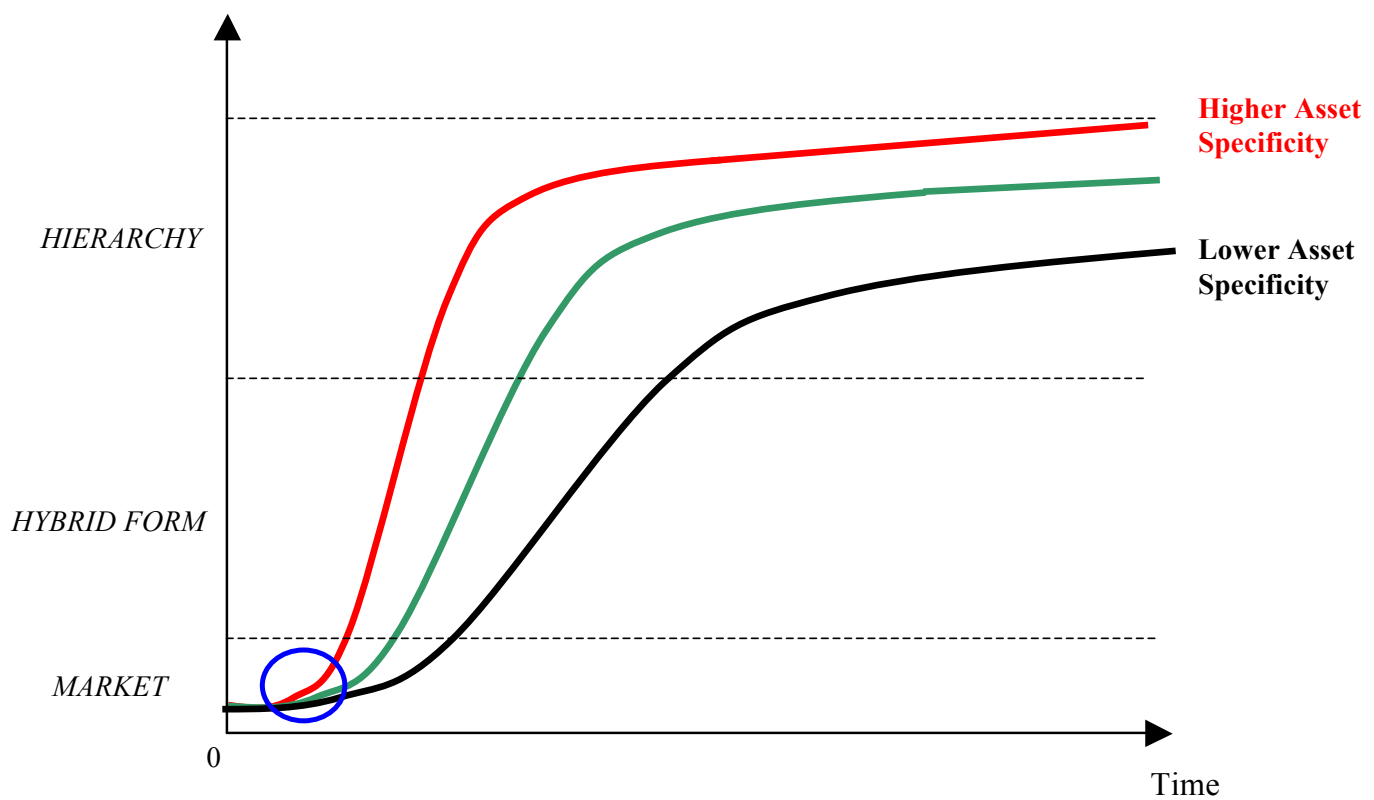

Figure 1 - Temporary Organizations Governance Structures (in the case of high, medium and low asset specificity)

Interestingly, the unique nature of the megaproject influences the choice of governance. To a large extent, stand-alone, highly novel megaprojects (such as major sporting events or unique infrastructure) would be located near the blue circle, whereas the success of more repetitive ones (such as standard construction or road or rail infrastructure projects) would be more likely to be based on a higher degree of internalisation present in the north-east section of the graph - assuming similar megaprojects relied on comparable resources, transactions and contracts in the past. In particular, repetitive megaprojects 
would allow the emergence of direct knowledge created in the course of first-hand with individuals and due to shared experience and understood communication (Cramton, 2001: 347).

That is to say the organisational structure is a function of both the asset specificity and the level of organizational permanency. As the duration of the project/organization is reduced, the optimal strategy is to 'buy' and adopt a market structure. As the project time increases the structure changes as more is done in-house until a hierarchy is reached. The timescale over which these transitions occur depends on the asset specificity; that is to say as the asset specificity of the project decreases the time required for a transition increases. If the asset specificity is very low then the transition may never occur. Figure 2 shows the same information as in Table 1 whereby a short-term project (temporary organization) is likely to adopt a market structure regardless of asset specificity whereas a permanent organisation (large time available and permanency) is more likely to adopt a hierarchy as the asset specificity increases.

\section{CONCLUDING REMARKS}

From a theoretical perspective, this chapter has shown the extent to which organisational theory can enable a better understanding of megaprojects governance structures and management. The limits of the transaction cost approach in the explanation of such temporary organizations led us to question a governance paradox and paved the way to a governance solution based on communities of practice as new forms of governance in the case of major projects. These conceptual results linked with the frequent stand-alone nature of megaprojects outlined the need for communication and knowledge transfers during the interaction in a context of community of practice. This essentially arises from the fact that individuals often proceed without common knowledge falsely thinking that what is said could be understood on the basis of their own experience and interpretation of the situation. As a result, communication should be based on trust-facilitating behaviours both to facilitate trust early and to maintain trust later in the project. To a certain extent, this idea corroborates existing contributions which refer to social 
communication and communication of enthusiasm to facilitate early trust and predictable communication and substantial and timely responses to maintain trust later (Jarvenpaa, Leidner, 1999: 807).

In addition, the non-permanency distinctive feature of megaprojects makes transaction costs based solutions difficult to apply in reality. This chapter has shown that beyond asset specificity, the level of organizational permanency has a direct influence on the governance choice made by the megaproject manager. This result is particularly relevant to the case of very large projects but could also be valid in a series of smaller projects.

Two main extensions of this chapter could be made in future research. First, a new avenue of research could be explored and debated and is directly linked to the results raised by this chapter. Beyond the non-permanency feature of megaprojects, these temporary organizational forms are also often defined by virtual teams, that is to say megaprojects that rapidly emerge, reorganize and disappear when the deadline is met and that gather individuals with diverse skills and competencies who are geographically dispersed and culturally different. Communication issues in this category of projects are also central to their success. While a series of recent contributions (Bell, Kozlowski, 2002; Zolin et al., 2004; Gibson, Gibbs, 2006; Wilson et al., 2008) developed research on global virtual teams, very little has been made regarding the specificities of megaprojects. Second, while this book chapter is, so far, mainly based on theoretical developments, future research could be supported by a grounded exploration that outlines the communication tools and routines developed in the governance context of a megaproject. In analysing these specific governance structures in different categories of megaprojects, focus could be made on the emergence of communities of practice as a solution to the governance paradox. 


\section{References}

Amin A., Cohendet P., (2004), Architectures of Knowledge - Firms, Capabilities and Communities, Oxford University Press.

Antonelli C., (2003), "The Governance of Technological Knowledge: Strategies, Processes and Public Policies", Working Paper Series, Dipartimento di Economia "S. Cognetti de Martiis", Laboratorio di Economia dell'Innovazione "Franco Momigliano, University of Turin, Italy.

Arena R., Conein B., (2008), "On Virtual Communities: Individual Motivations, Reciprocity and We-Rationality”, International Review of Economics, 55(1-2): 185-208.

Bacharach M., (2005), "Foreword: Teamwork", in Gold, Teamwork - Multi-Disciplinary Perspectives, Palgrave Macmillan: xxi-xxv.

Bell B. S., Kozlowski S. W. J, (2002), "A Typology of Virtual Teams : Implications for Effective Leadership", Group \& Organization Management, 27(1) : 1-49.

Coase R.H., (1937), “The Nature of the Firm”, Economica, 4(16): 386-405.

Cramton C.D., (2001), "The Mutual Knowledge Problem and its Consequences for Dispersed Collaboration", Organization Science, 12(3): 346-371.

Cohendet P., Creplet F., Dupouët O., (2001), "Communities of practice and epistemic communities: a renewed approach of organizational learning within the firm", presented at the "Workshop on Economics and Heterogeneous Interacting Agents", Marseille, June, 2001.

Cummings L.L., Bromiley P., (1996), "The organizational trust inventory (OTI): Development and validation", in Kramer R.M., Tyler T.R., Eds., Trust in Organizations: Frontiers of Theory and Research. Sage Publications, Thousand Oaks, CA : 302-330.

Dupouët O., Yildizoglu M., Cohendet P., (2003), "Morphogenese de communautes de pratique", Revue d'Economie Industrielle, (103): 91-110.

Eccles R., (1981), "The Quasi-Firm in the Construction Industry", Journal of Economic Behavior and Organization, 2(4): 335-357.

Eisenhardt K., (1989), "Building Theories from Case Study Research", Academy of Management Review, 14(4): 532-550.

Flyvbjerg B., (2006), "From Nobel Prize to Project Management: Getting Risks Right", Project Management Journal, 37(3): 5-15.

Flyvbjerg B., (2005a), "Design by Deception: The Politics of Megaproject Approval", Harvard Design Magazine, 22, Spring/Summer: 50-59.

Flyvbjerg, B., (2005b), "Measuring Inaccuracy in Travel Demand Forecasting: Methodological Considerations Regarding Ramp Up and Sampling”, Transportation Research A., 39(6): 522-530.

Flyvbjerg, B., Skamris Holm, M.K., Buhl, L.S., (2002), "Underestimating Costs in Public Works Projects: Error or Lie?", Journal of the American Planning Association, 68(3): 279-295.

Flyvbjerg, B., Skamris Holm, M.K., Buhl, S.L., (2004), "What Causes Cost Overrun in Transport Infrastructure Projects?", Transport Reviews, 24(1): 3-18

Flyvbjerg, B., Skamris Holm, M.K, Buhl, S.L. (2005), "How (In)accurate Are Demand Forecasts in Public Works Projects? The Case of Transportation", Journal of the American Planning Association, 71(2): 131-146 
Flyvbjerg, B., Garbuio, M., Lovallo, D., (2009), "Delusion and deception in large infrastructure projects: Two models for explaining and preventing executive disaster", California Management Review, 51(2): 170 -193.

Ghoshal S., Moran P., (1996), "Bad for Practice: A Critique of the Transaction Cost Theory", Academy of Management Review, 21(1): 13-47.

Gibson C. B., Gibbs J. L., (2006), "Unpacking the Concept of Virtuality : The Effects of Geographic Dispersion, Electronic Dependence, Dynamic Structure, and National Diversity on Team Innovation", Administrative Science Quarterly, (51) : 451-495

Gilbert M., (2005), “A Theoretical Framework for the Understanding of Teams”, in Gold, Teamwork - Multi-Disciplinary Perspectives, Palgrave Macmillan: 22-32.

Gioia D.A., Thomas J.B., Clark S.M., Chittipeddi K., (1994), "Symbolism and Strategic Chance in Academia: The Dynamics of Sensemaking and Influence", Organization Science, 5(3): 363-383.

Glaser B.G., Strauss A. L., (1967), The Discovery of Grounded Theory: Strategies for Qualitative Research, Chicago, Aldine Publishing Company.

Gold N., (2005a), Teamwork - Multi-Disciplinary Perspectives, Palgrave Macmillan.

Gold N., (2005b), "Introduction: Teamwork in Theory and in Practice", in Gold, Teamwork Multi-Disciplinary Perspectives, Palgrave Macmillan: 1-21.

Hodgson D.E., (2004), "Project Work: The Legacy of Bureaucratic Control in the PostBureaucratic Organization", Organization, 11(1): 81-100.

Jarvenpaa S.L., Leidner D.E., (1999), "Communication and Trust in Global Virtual Teams", Organization Science, 10(6): 791-815.

Knorr Cetina K., (1999), Epistemic Cultures: How the Sciences Make Knowledge, Harvard University Press.

Kramer R.M., Tyler T.R., Eds., (1996), Trust in Organizations: Frontiers of Theory and Research. Sage Publications, Thousand Oaks, CA.

Menard C., (1997), "Le pilotage des formes organisationnelles hybrides", Revue Economique, 48(3) : 741-750.

Menard C., (2004), "The Economics of Hybrid Organizations", Journal of Institutional and Theoretical Economics, 160(3): 345-376.

Meyerson D., Weick K.E., Kramer R.M., (1996), "Swift trust and temporary groups", in R. M. Kramer, T. R. Tyler, eds. Trust in Organizations: Frontiers of Theory and Research. Sage Publications, Thousand Oaks, CA : 166-195.

Miles M.B., Huberman A.M., (1984), Qualitative data analysis: A source book of new methods, Beverly Hills, CA: Sage.

Moingeon B., Quélin B., Dalsace F., Lumineau F., (2006), "Inter-Organizational Communities of Practice: Specificities and Stakes", HEC Working Paper, n857, 18 pages.

Nag R., Corley K., Gioia D., (2007), "The Intersection of Organizational Identity, Knowledge and Practice: Attempting Strategic Change via Knowledge Grafting", Academy of Management Journal, 50(4): 821-847. 
Oliver A., Ebbers M., (1998), "Networking Network Studies: An Analysis of Conceptual Configurations in the Study of Inter-Organizational Relationships," Organization Studies, 19(4): 549-583.

Peltokorpi V., Tsuyuki E., (2007), "Organizational Governance in Internal Hybrids: A Case Study of Maekawa Manufacturing Ltd.”, Corporate Governance, 7(2): 123-135.

Powell W.W., (1990), "Neither Market Nor Hierarchy: Network Forms of Organization", Research in Organizational Behavior, (12): 295-336.

Priemus H., Flybjerg B., van Wee B., (2008), Decision-Making on Mega-Projects: Cost-Benefit Analysis, Planning and Innovation, Edward Elgar.

Rands T., (1992), "The Key Role of Applications Software Make-or-Buy Decisions", Software Acquisition Decisions, 1(4): 215-223.

Riordan M.H., Williamson O.E., (1985), "Asset Specificity and Economic Organization", International Journal of Industrial Organization, 3(4): 365-378.

Turner J.R., Keegan A., (2001), "Mechanisms of Governance in the Project-Based Organization: Roles of the Broker and the Stewart", European Management Journal, 19(3): 254267.

Van Donk D., Molloy E., (2008), "From Organising as Projects to Projects as Organisations", International Journal of Project Management, 26(2): 129-137.

Wenger E., (1998), Communities of Practice - Learning, Meaning and Identity, Cambridge University Press.

Wenger E., McDermott R., Snyder W.M., (2002), Cultivating Communities of Practice: A Guide to Managing Knowledge, Boston: Harvard Business School Press.

Williamson O.E., (1975), Markets and Hierarchies: Analysis and Antitrust Implications, New York: Free Press.

Williamson O.E., (1981), "The Economics of Organization: The Transaction Cost Approach", American Journal of Sociology, 87(3): 548-577.

Williamson O.E., (1985), The Economic Institutions of Capitalism: The Free Press-Macmillan: New York.

Williamson O.E., (1991), "Comparing Economic Organizations: The Analysis of Discrete Structural Analysis", Administrative Science Quarterly, 36(2): 269-296.

Williamson O.E., (1999), "Strategy Research: Governance and Competence Perspectives", Strategic Management Journal, 20(12): 1087-1108.

Williamson O.E., (2002), "The Theory of the Firm as Governance Structure: From Choice to Contract”, Journal of Economic Perspectives, 16(3): 171-195.

Williamson O.E., (2005a), "The Economics of Governance”, American Economic Review, 95(2): $1-18$.

Williamson O.E., (2005b), "Transaction Cost Economics and Business Administration", Scandinavian Journal of Management, (21): 19-40.

Wilson J.M., Boyer O'Leary M., Metiu A., Jett Q.R., (2008), "Percieved Proximity in Virtual Work: Explaining the Paradox of Far-but-Close", Organization Studies, 29(07): 979-1002. 
Zolin R., Hinds P.J., Fruchter R., Levitt R. E., (2004), "Interpersonal Trust in CrossFunctional, Geographically Distributed Work: A Longitudinal Study", Information and Organization, (14): 1-26. 